\title{
Long Term Analysis of Optical and Radiative Properties of Aerosols in the Amazon Basin
}

\author{
Rafael da Silva Palácios ${ }^{1 *}$, Kelly Sousa Romera ${ }^{1}$, Leone Francisco Amorim Curado ${ }^{\mathbf{1}}$, \\ Nelson Mario Banga ${ }^{1}$, Lucas Douglas Rothmund ${ }^{1}$, Fernando da Silva Sallo ${ }^{3}$, Denes Morais ${ }^{4}$, \\ Anna Carolinna Albino Santos ${ }^{4}$, Tonny Jader Moraes ${ }^{1}$, Fernando Gonçalves Morais ${ }^{5}$, \\ Eduardo Landulfo ${ }^{5}$, Marco Aurélio de Menezes Franco ${ }^{6}$, Igor Antonio Kuhnen, \\ João Basso Marques ${ }^{1}$, José de Souza Nogueira ${ }^{1}$, Luiz Claudio Galvão do Valle Júnior², \\ Thiago Rangel Rodrigues ${ }^{2}$
}

${ }^{1}$ Federal University of Mato Grosso (UFMT), Cuiabá 78060-900, Brazil

${ }^{2}$ Federal University of Mato Grosso do Sul (UFMS), Campo grande 79070-900, Brazil

${ }^{3}$ University of Cuiaba (UNIC), Cuiabá 78065-900, Brazil

${ }^{4}$ University of Varzea Grande (UNIVAG), Cuiabá 78118-900, Brazil

${ }^{5}$ Instituto of Research Energy and Nuclear (IPEN), São Paulo 05508-000, Brazil

${ }^{6}$ University of São Paulo (USP), São Paulo 05508-090, Brazil

\begin{abstract}
The Amazon region is an excellent laboratory for analysis of natural aerosols in the wet season; however, in the dry season the biomass burning emissions highly influence it, which considerably alters the physical and chemical properties of the atmosphere. We analyzed long-term time series (2000-2017) of optical and radiative properties of aerosols during dry and rain seasons from nine AERONET stations located in the Amazon Basin (Western Brazil). Aerosols have been classified into two groups: organic carbon (OC) and elemental carbon (EC), which allowed quantification of their effects on the radiative forcing for these sites. It was possible to conclude that the optical depth values of aerosols (AOD $500 \mathrm{~nm}$ ), which remained in a downward inclination beginning in 2010 to 2012, returned to rise since 2013. The analysis showed that the fraction of biogenic particles varied from approximately $38 \%$ to $67 \%$ at the site of Manaus EMBRAPA. However, for ATTO this fraction remained practically constant throughout the year, around $68 \%$ as the fraction of OC-EC went from approximately 16 to $27 \%$. In that way, the study found that in the central Amazon region, in the dry season, the OC fraction generates instantaneous effects of up to $-100 \mathrm{~W} \mathrm{~m}^{-2}$ in the radiative surface forcing (FR-Surface), while in the Cerrado region (Cuiabá) the instantaneous values reached up to $-350 \mathrm{~W} \mathrm{~m}^{-2}$. The impact of the primary biogenic particles on the radiative flux resulted in a mean, approximately $-20 \mathrm{~W} \mathrm{~m}^{-2}$ FR-Surface, representing $45 \%$ of the total effect caused by aerosols in the Amazon.
\end{abstract}

Keywords: Aerosol optical depth; Single scattering albedo; Angstrom matrix.

\section{INTRODUCTION}

Human activities have contributed strongly to the intense and continuous changes in the global climate is which has intensified since the Industrial Revolution (Hansen et al., 2013; Rap et al., 2013; Scott et al., 2018a). The constant intensification of factors such as deforestation, urbanization, and use of fossil fuels have influenced the radiative balance

\footnotetext{
* Corresponding author.

Tel.: +55 (65) 3313 7306; Fax: +55 (65) 33137306

E-mail address: rafael.pgfa@gmail.com
}

of Earth, changing the chemical composition of the atmosphere and the physical properties of the Earth's surface (Scott et al., 2018a, b). Climate changes observed over the last few years, such as the increase in average terrestrial temperature, modify the dynamics of the atmosphere and oceans, which in turn alter local and regional hydrological patterns causing an increase in occurrences of extreme events, such as prolonged droughts and floods (Spracklen et al., 2009; Carslaw et al., 2010).

Human activities are quickly changing the earth's surface, and this fact is evident especially in the tropics. Tropical forests, and in particular the Amazon rainforest, are suffering from high rates of deforestation and burning (Scott et al., 2018a). In the Amazon Basin, deforestation is not randomly 
distributed, the most impacted region coincides through the agriculture and pasture boundaries with the forest, this region is known as the "Deforestation Arc" and is located in the states of Maranhão, Pará, Tocantins, Mato Grosso, Rondônia and Acre (Martin et al., 2016; Scott et al., 2018a). This region is a site of intense agricultural activities, often followed by intense logging fires, which are either spontaneous or planned by man and occur mainly during the dry season. Particulate matter released into the atmosphere by these activities directly affects the radiative balance between the atmosphere and the biosphere through the absorption and scattering of solar radiation. In the direct effect, both absorption and scattering influence the fluxes of radiation directly incident on the surface and its reflected component to the top of the atmosphere (Arneth et al., 2010; Poschl et al., 2010).

Large loads of burnt aerosols affect the Amazon Basin in the dry season, and the plumes generated in these burnings strongly impact local and regional radiative flows (Artaxo et al., 2013; Sena et al., 2013). Some of the effects of the burning plumes have already been studied in this region (Artaxo et al., 2013; Sena et al., 2013). In particular, some studies evaluated the effects of natural aerosols in the Amazon region (Martin et al., 2016; Scott et al., 2018b). However, several issues related to the interaction of natural aerosols with direct solar radiation remain open to discussion. In the wet season, a condition practically free of burnt aerosols, the intense metabolism of the Amazon forest emits into the atmosphere natural particles that form the set of aerosols called primary biogenic aerosols (Artaxo et al., 2013). During the dry season, the high number of condensation nuclei changes the microphysics and the optical properties of the clouds, influencing the processes of convection and precipitation (Martin et al., 2016; Scott et al., 2018b). Whereas in the wet season the low number of aerosols that act as condensation nuclei (formed essentially by biogenic aerosols) characterize clouds similar to those found on the oceans, which is why the Amazon is also called the "Green Ocean" (Martin et al., 2016; Scott et al., 2018b).

Changes in radiation fluxes caused by aerosols can interfere with surface temperature and thereby alter the sensible and latent heat fluxes in the layers near the surface. These changes can modify the vertical profile of temperature, height of the boundary layer, local and regional circulation and rates of cloud formation and precipitation (Hallquist et al., 2009; Poschl et al., 2010; Martin et al., 2016). The disturbance caused by the aerosols in the radiative balance contrasts to the effect of the gases in several aspects, among them the fact that particulate matter generally has a short average lifetime in the atmosphere, unlike most greenhouse gases, ranging from hours to weeks. Thus, the spatial distribution of the aerosol concentration has a great heterogeneity, because it depends heavily on sources and transport mechanisms. These facts make it difficult to analyze the global effects of aerosols on climate (Ward et al., 2012; Scott et al., 2014; Andreae et al., 2015).

In this way, the present work sought to broaden the understanding of the interaction of solar radiation with atmospheric aerosol particles in the Amazon Basin, in the dry and wet seasons, through a long series of measurements by remote surface sensing (AERONET network). In addition to characterizing the seasonal and interannual differences of the optical and radiative properties of the aerosols in forest and Cerrado sites, the fractions of organic carbon (OC) and elemental carbon (EC) were also separated, which allowed quantification of their effects on the radiative forcing of each site.

\section{EXPERIMENTAL METHODS}

\section{Study sites}

This research evaluated the optical properties of aerosols in nine sites of the AERONET network, shown in Fig. 1. Table 1 hold the sites with their respective geographic coordinates and data periods available and used. Eight of the studied sites are within the limits of the Legal Amazon and only the site of Campo Grande (Campo Grande SONDA) is not part of this region. This site was taken into account due to its local characteristics, which allowed the comparison of the optical properties of the aerosols in that site with those of the site of Cuiabá (Cuiabá Miranda). This is necessary, since both belong to the Cerrado biome and are directly impacted by the biomass burning of the Deforestation Arc.

The sites of ATTO (Amazon ATTO Tower) and Manaus (Manaus EMBRAPA) are located upwind of the plume of Manaus, whereas the Manacapuru site (ARM Manacapuru) is located downwind. The ATTO site is about $160 \mathrm{~km}$ north of Manaus, in the region, where hundreds of $\mathrm{km}$ of undisturbed forest-covered areas extend. The origin of the air masses on the ATTO site varies throughout the year, depending on the seasonal variation of the Intertropical Convergence Zone (ITCZ) over the Amazon Basin, which results in large changes in meteorological conditions and atmospheric composition (Andreae et al., 2012). During the wet season, air masses arrive predominantly from the northeast region of the ATTO,

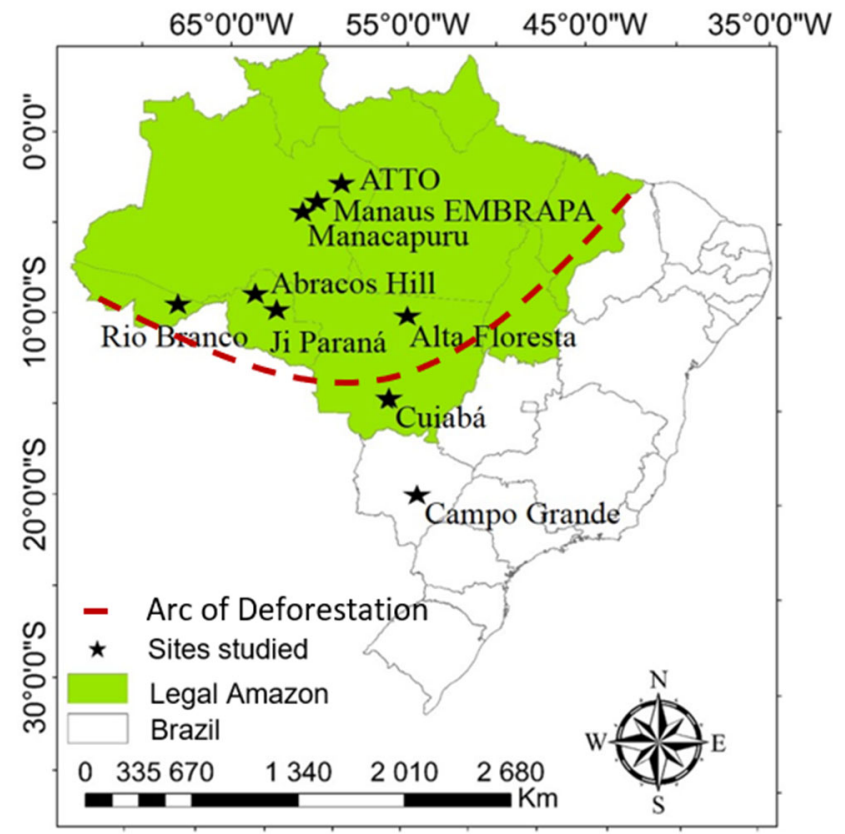

Fig. 1. Location of analyzed AERONET sites. 
Table 1. Coordinates and sampling period of radiometers used in this work.

\begin{tabular}{llcl}
\hline \multirow{2}{*}{ Site } & \multicolumn{2}{c}{ Localization } & Period \\
\cline { 2 - 4 } & Latitude $\left({ }^{\circ} \mathrm{S}\right)$ & Longitude $\left({ }^{\circ} \mathrm{W}\right)$ & $2016-2017$ \\
\hline ATTO & 2.14 & 59.00 & $2011-2017$ \\
Manaus & 2.89 & 59.97 & $2013-2015$ \\
Manacapuru & 3.21 & 60.59 & $2000-2017$ \\
Alta Floresta & 9.87 & 56.10 & $2006-2015$ \\
Ji Paraná & 10.93 & 61.85 & $2000-2017$ \\
Rio Branco & 9.96 & 67.87 & $2000-2005$ \\
Abracos Hill & 10.76 & 62.35 & $2000-2017$ \\
Cuiabá & 15.73 & 56.02 & $2003-2017$ \\
Campo Grande & 20.44 & 54.54 & \\
\hline
\end{tabular}

over miles of primary forest cover. During this period, longdistance transport events from the Atlantic and Africa brought episodes of marine aerosols, Sahara sand, and West African biomass burning. At the end of May, this pattern changes abruptly due to the displacement of the ITCZ to the north of the region, in this case, the site samples air masses of the Southern Hemisphere.

The site of Manaus is located approximately $25 \mathrm{~km}$ north of the municipality of Manaus in the Brazilian Agricultural Research Corporation (EMBRAPA) (Barbosa et al., 2014). This region is also located on the top of the plume of Manaus so that the characteristics of this region are very similar to that of the ATTO site, however, there is also a predominance of pastures. The Manacapuru site is located downwind in the Manaus plume, which suffer direct impact by the urban emissions of both the municipality of Manaus and Manacapuru, which belongs to the metropolitan region of Manaus, located approximately $100 \mathrm{~km}$ away. The installation of the AERONET radiometer in Manacapuru was part of a field campaign of the GoAmazon experiment, which aims to investigate and understand how the pollutants of Manaus in the middle of the tropical forest can influence the life cycle of aerosols and clouds (Martin et al., 2016).

The sites of Alta Floresta, Abracos Hill, Ji Paraná (Ji Paraná SE), and Rio Branco are located in the Deforestation Arc and strongly impacted by the burnt aerosols. The site of Alta Floresta (State of Mato Grosso) is located in the south of the Amazon Basin, a transition area between forest and pasture, presenting the largest record of burn outbreaks in Brazil. The sites of Ji Paraná and Abracos Hill are installed in pasture areas, and the Rio Branco site is located in a region near the urban center of this city.

The Cuiabá and Campo Grande sites are part of the Cerrado, and Cuiabá is located in the Cerrado-Pantanal transition zone. The radiometer for this site is located approximately $20 \mathrm{~km}$ from the urban perimeter, in a region with small trees and twisted branches, amidst a mixture of pasture and flooded surfaces. Campo Grande is located in a rural area, also close to the limits of the urban area. Around this site, there is a predominant vegetation of Cerrado and urban parks of conservation areas. Both sites are directly influenced by local biomass burning in the dry season.

\section{Database, AErosol RObotic NETwork (AERONET)}

AERONET (AErosol RObotic NETwork) is a global remote sensing aerosol monitoring network, installed at surface level and maintained by NASA's Earth Observing System (EOS) (Holben et al., 1998). AERONET equipment embraces a series of automatic and identical spectral radiometers distributed by the planet Earth. The measurements allow the near real-time monitoring of the optical thickness of the aerosols, precipitating water column and particle size distribution, among other physical and optical properties of aerosols. The products supplied by AERONET are freely available online at http://aeronet.gsfc.nasa.gov/, which contains all the information about the monitoring system.

The AERONET network follows a protocol for data quality assurance, divided according to the level of processing, which varies between 1.0, 1.5 and 2.0. Level 1.0 data represents gross measurements, with no corrections and with all points acquired by the photometer. Level 1.5 has processed measures that eliminate cloud and rain contamination. At the 2.0 level, a cut is made for the optical depth of the aerosol in the channel of $440 \mathrm{~nm}$ (AOD $440 \mathrm{~nm}$ ), the AOD in $440 \mathrm{~nm}$ has to be greater than 0.4 , which minimizes uncertainty for AOD values ranging from 0.01 to 0.02 (Eck et al., 1999).

In this work, were used the direct products of level 1.5 and 2.0, since the values of AOD are extremely low in the Amazon region during the wet season. In the characterizations developed in this study were used the products of AOD at $500 \mathrm{~nm}$ of level 2.0 and the products of inversion: single scattering albedo (SSA), scattering aerosol optical depth (SAOD), absorption aerosol optical depth (AAOD), refractive index (IR), volumetric size distribution (VSD), absorption Angstrom exponent (AAE), extinction Angstrom exponent (EAE), aerosols radiative forcing to the surface (ARF $F_{S U R}$, level 1.5.

\section{Methods of Analysis}

The Angstrom exponent can be derived for both scattering and absorption. The scattering component (SAE) represents the spectral dependence of the scattering coefficient $b_{\text {scat }}$ or the scattering optical thickness $\left(\tau_{\text {scat }}\right)$ with the wavelength. The values of the scattering Angstrom exponent have direct relation to the average particle size. In the case of a unimodal size distribution, SAE values greater than 2.0 indicate the predominance of fine-mode particles, which are usually associated with urban pollution or biomass burning. SAE values close to 1.0 indicate the presence of coarse-mode particles, typically associated with sea salt and mineral dust 
(Schuster et al., 2006). Analogously, the absorption Angstrom exponent (AAE) represents the spectral dependence of the absorption coefficient $\left(b_{a b s}\right)$. This optical parameter have relation to the physical and chemical properties of the aerosol (Rizzo et al., 2011). Black carbon (BC), for example, has a $\lambda^{-1}$ spectral dependence, which give us an AAE equal to 1.0 (Bergstrom et al., 2002), and for the aerosols of OC from the biomass burning the absorption of radiation is more significant in ultraviolet (UV) spectral regions, resulting in AAE values greater than 1.0 (Kirchstetter, 2004). AAE values greater than 1.5 are commonly observed in mineral dust aerosols (Russell et al., 2010).

AERONET's inversion products were explored in the discussion of scattering and absorption of radiation by aerosols in the atmospheric column, quantifying the radiative forcing and the radiative forcing efficiency for all sites. Linear regressions were carried out to evaluate the influence of radiation absorption and scattering on the descending radiative flux on the surface and ascending at the top of the atmosphere in the dry and wet seasons for each site. The influence of fractions of $\mathrm{EC}, \mathrm{OC}$ and biogenic particles on the radiative flux was quantified. The optical property measurements for forest regions in the wet season were used to model the optical properties of the primary biogenic aerosol, quantifying its effect on the radiative flux.

\section{RESULTS AND DISCUSSION}

\section{Variability of Optical Depth of Aerosols}

The entire region of the Amazon Basin, as well as much of the South American continent, exhibits a significant change in the optical properties of aerosols during the dry season (Hoelzemann et al., 2009). The temporal distribution of the optical depth of the aerosol at $500 \mathrm{~nm}$ (AOD $500 \mathrm{~nm}$ ) shows the seasonality of the values of AOD $500 \mathrm{~nm}$. That according to Sena et al. (2013) and Artaxo et al. (2013) occur due to the high rates of burn outbreaks in the dry season in both the southern region of the Amazon rainforest and in the entire central-west region of Brazil, as seen in Fig. 2. The great variability in aerosol composition over the southern Amazon region in the dry season is due to the biomass burning in the Deforestation Arc region, which is highly related to the variability of the AOD $500 \mathrm{~nm}$ over this region (Fuzzi et al., 2007).

Between the 2004 and 2012 years, in the Legal Amazon, it occurs a significant reduction in the deforestation rate, from $27800 \mathrm{~km}^{2} \mathrm{ano}^{-1}$ to $4660 \mathrm{~km}^{2} \mathrm{ano}^{-1}$ (INPE-PRODES, 2018) or, about six times. However, the deforestation rates and the number of fires do not follow the same temporal trend. The reduction in deforestation rates (from 2004 to 2012) were not observed for number of fires. This can indicates a fire-use change that initially is associated to areas already deforested and currently to pasture and crop landuse management (Ten Hoeve et al., 2012). The arc of deforestation region, localized in the south of Amazon river basin, is also a agricultural frontier that presents record fires number in dry season (Ten Hoeve et al., 2012; Artaxo et al., 2013).

The years 2005 and 2010 are reported particularly by the works of Marengo et al. (2008) and Marengo et al. (2011) respectively, as well as a large amount of carbon released into the atmosphere in these two large drought records. The relationship between the burning records in Brazil and the values of the AOD $500 \mathrm{~nm}$ shows that both the Amazon forest region and the Cerrado regions have direct correlation by the biomass burning. In Fig. 2, it is possible to observe

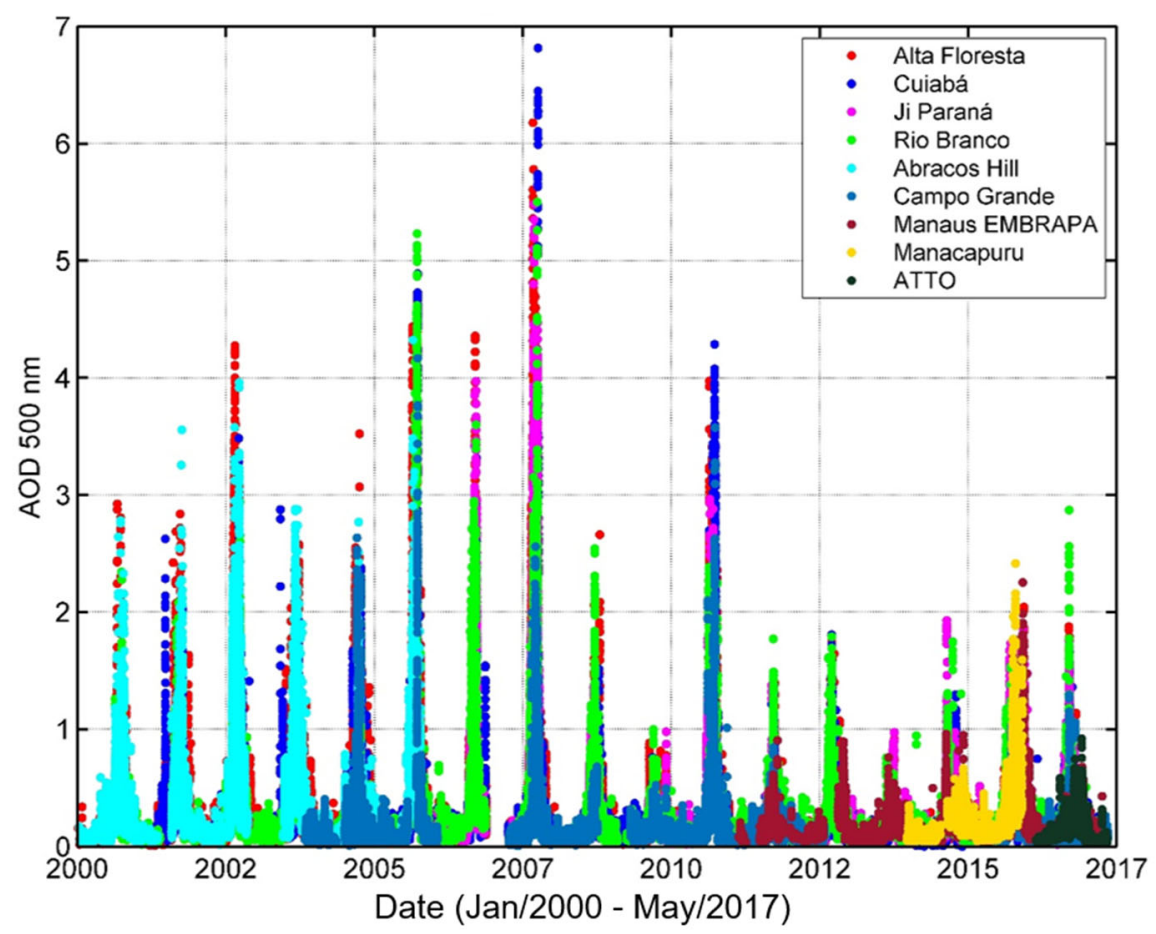

Fig. 2. Time series of AOD $500 \mathrm{~nm}$ for all sites analyzed from January 2000 to May 2017. 
that the highest aerosol loads occur in the sites of Alta Floresta, Cuiabá, Ji Paraná, Rio Branco, and Abracos Hill. Although the Cuiabá site is not located in the region of the arc of Amazonian deforestation, the values of AOD $500 \mathrm{~nm}$ are as high as those found in the Alta Floresta site, because in addition to local burnings typical of Cerrado and pasture, this region also influenced by transport of particles from the south of the Amazon Basin. The sites that less impacted by biomass burning are located in central Amazonia (Manaus EMBRAPA, Manacapuru, and ATTO). In addition, these sites did not include 2005, 2007 and 2010 measures that were those with severe droughts in the Amazon region, provoking historical records of fires in Brazil (Marengo et al., 2008; Marengo et al., 2011; Ten Hoeve et al., 2012).

In Fig. 2, the maximum values for AOD $500 \mathrm{~nm}$ are increasing from the year 2013, so that the increase in deforestation rates is directly influencing the aerosol load emitted into the atmosphere, this increase in AOD values of $500 \mathrm{~nm}$ is noticeable both in sites located in the arc of deforestation and in the central region of the Amazon. The maximum value of AOD $500 \mathrm{~nm}$ went from approximately 0.8 in 2013 to 1.5 in 2015 on the site of Rio Branco. For the Manaus EMBRAPA site, this increase was even more evident, ranging from 0.8 in 2013 to 2.3 in 2015. For Manacapuru, this increase in the values of AOD $500 \mathrm{~nm}$ have been observed for the year 2015 compared to 2014, rising from 0.8 in 2014 to 2.4 in 2015 . The report of this variation is unprecedented, since the time series of AOD $500 \mathrm{~nm}$ followed a downward trend until the year 2013, accompanying the reductions of annual rates of deforestation in the Amazon. However, from the year 2013, the general trend on the AOD $500 \mathrm{~nm}$ series has been increasing again, as well as the annual rates of deforestation, evidencing that deforestation in the Amazon has a direct impact on the aerosol load.

The work of Sena et al. (2013) reported in a time series of annual deforestation rates and annual average of AOD 550 nm (1988-2012) that even after the regions are deforested the values of AOD $550 \mathrm{~nm}$ remain high. That suggest that the fires move to the Cerrado region, since even decreasing rates of deforestation mean annual values of AOD $550 \mathrm{~nm}$ remain high. The increase in deforestation rates has a direct impact on the aerosol loads emitted in the Amazon, however, even if there is a reduction in deforestation rates, the aerosol loads still take some time to take a downward trend. This work suggests that deforested areas not burned immediately at the time of deforestation but carried out in later periods, causing a gap between deforestation and high AOD recorded by biomass burning.

The sites located in central Amazonia also show seasonal variations, which means that they also are impacted by the emissions of fires. For low values of AOD $500 \mathrm{~nm}$, a good coherence between the data of Manaus EMBRAPA and ATTO is observed, that is, in free conditions of the action of the fires these distributions are very similar. However, for the values of AOD $500 \mathrm{~nm}$ above 0.3 , a dispersion between measurements is observed, with the highest values occurring over EMBRAPA. Considering the months from January to June as wet season and from July to December as the dry season, the averages for the rainy and dry seasons respectively for the site of Manaus EMBRAPA were $0.09 \pm 0.05$ and 0.20 \pm 0.10 and for the ATTO site of $0.09 \pm 0.04$ and $0.18 \pm 0.09$. The mean values and their respective deviations for the rainy season clearly demonstrated that there is no difference for the values of AOD $500 \mathrm{~nm}$ between the two sites. Already for the dry season, the averages for the AOD $500 \mathrm{~nm}$ on the site of Manaus EMBRAPA were slightly higher, however, within the deviation values, there is practically no difference between the means for the AOD $500 \mathrm{~nm}$ between the ATTO, and Manaus EMBRAPA.

\section{Scattering and Absorption Properties in the Atmospheric Column}

Fig. 3, illustrate the spectral dependence of the absorption (AAOD) and scattering aerosol optical depth (SAOD) for the dry and rainy seasons of each site. That shows the strong dependence of both the AAOD and the SAOD with the wavelength. The highest absorption and scattering values occur at $440 \mathrm{~nm}$. Among the sites most impacted by the fires in the dry season, Cuiabá stands out for its absorption values. The sites located in the arc of deforestation (Alta Floresta, Ji Paraná, Rio Branco, and Abracos Hill) presented similar behaviors. The site of Manacapuru presented in the dry season an AAOD near the values found in the sites belonging to the arc of deforestation, while the sites of Manaus EMBRAPA and ATTO presented extremely low values for AAOD both in the dry season and in the wet season. Table 2 shows the mean values and their deviations for AAOD and SAOD at $440 \mathrm{~nm}$ for the dry and wet seasons for the sites studied.

The Campo Grande site, although similar to that of Cuiabá, presented a very distinct behavior, with low values of AAOD in the dry season, which suggests that the effects of biomass burning may be different in these two typical Cerrado regions. In the wet season, Campo Grande has values of AAOD similar to the values found for the site of Manaus EMBRAPA and is very close to those found for ATTO. For SAOD, Campo Grande has the lowest values of all the analyzed sites. In the dry season, the aerosols on Campo Grande become more absorptive and their values of AAOD exceed the values found in Manaus EMBRAPA and ATTO, however, still below the values found for the other sites. For SAOD in the dry season, the values of Campo Grande remain low, similar to the values found in Manaus EMBRAPA.

The values of SAOD found in Cuiabá in the dry season are similar to the values found in Rio Branco, in the arc of deforestation and close to those found in Manacapuru. The highest values of SAOD in the dry season occurred in the sites of Abracos Hill, Ji Paraná, and Alta Floresta, evidencing that the biomass burning contributes significantly to the radiation scattering. The fact that Campo Grande has low SAOD values both in the dry season and in the wet season, as well as low AAOD values in the wet season (values close to those found in central Amazonia) may be related to the location of the AERONET radiometer, where there are several parks and conservation areas near this site. The increase in dry season AAOD values is due to the Cerrado burning; however, it is observed that this impact is much lower than that found in Cuiabá. Fig. 4 shows the typical annual variability for the values of AAOD and SAOD at 

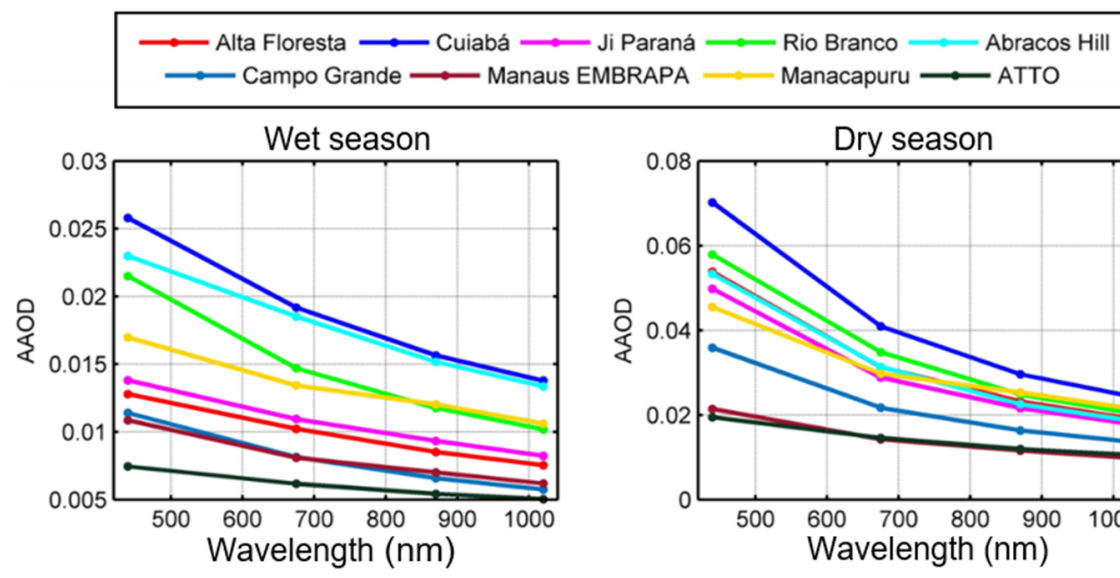

Wet season
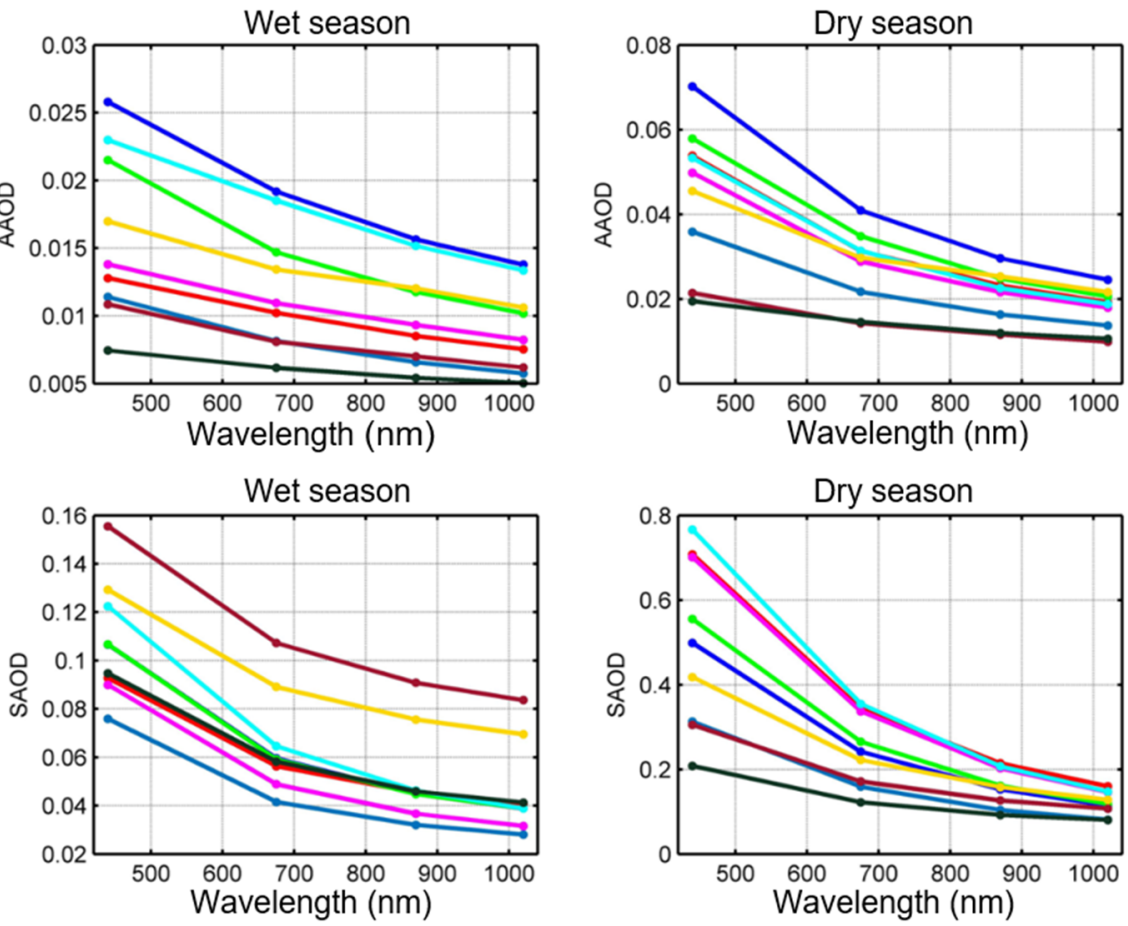

Fig. 3. Spectral dependence of AAOD and SAOD for the dry and wet seasons of each site.

Table 2. Mean values (with respective deviations) for AAOD and SAOD at $440 \mathrm{~nm}$ of the dry and wet seasons of each analyzed site.

\begin{tabular}{|c|c|c|c|c|}
\hline \multirow{2}{*}{ Site } & \multicolumn{2}{|c|}{ Dry season } & \multicolumn{2}{|c|}{ Wet season } \\
\hline & AAOD & SAOD & AAOD & SAOD \\
\hline Alta Floresta & $0.05 \pm 0.05$ & $0.70 \pm 0.70$ & $0.01 \pm 0.01$ & $0.09 \pm 0.13$ \\
\hline Cuiabá & $0.07 \pm 0.07$ & $0.49 \pm 0.48$ & $0.02 \pm 0.02$ & $0.10 \pm 0.12$ \\
\hline Ji Paraná & $0.04 \pm 0.03$ & $0.70 \pm 0.67$ & $0.01 \pm 0.01$ & $0.08 \pm 0.06$ \\
\hline Rio Branco & $0.05 \pm 0.05$ & $0.55 \pm 0.50$ & $0.02 \pm 0.01$ & $0.10 \pm 0.12$ \\
\hline Abracos Hill & $0.05 \pm 0.03$ & $0.76 \pm 0.56$ & $0.02 \pm 0.02$ & $0.12 \pm 0.10$ \\
\hline Campo Grande & $0.03 \pm 0.02$ & $0.31 \pm 0.36$ & $0.01 \pm 0.01$ & $0.07 \pm 0.07$ \\
\hline M. EMBRAPA & $0.02 \pm 0.02$ & $0.30 \pm 0.21$ & $0.01 \pm 0.01$ & $0.15 \pm 0.16$ \\
\hline Manacapuru & $0.04 \pm 0.03$ & $0.41 \pm 0.29$ & $0.01 \pm 0.01$ & $0.12 \pm 0.13$ \\
\hline ATTO & $0.01 \pm 0.01$ & $0.20 \pm 0.08$ & $0.01 \pm 0.01$ & $0.09 \pm 0.01$ \\
\hline
\end{tabular}

$440 \mathrm{~nm}$, presenting the effect of aerosols on the extinction of radiation throughout the year. The shaded region (Fig. 4) highlights the period with the maximum records of fires in Brazil, it is possible to observe that the scattering effect is predominant in the extinction of the radiation in both analyzed regions. However, the amplitude of the spreading and absorption events are higher over the Alta Floresta region, since this site has direct influence by the emissions in the Deforestation Arc. The site of Manaus EMBRAPA presented low values of scattering and absorption even for the period considered as dry season, it should be noted that the period corresponding to the maximum scattering and absorption values extends to the month of November. Differently from the sites located in the region of the Deforestation Arc and in the Cerrado, local burns may influence the regions located closer to the center of the Amazon Basin. In the Amazon region, precipitation rates are very high, which makes it difficult to burn the forest, so farmers clear the forest at the end of the rainy season (May-June) and let the chopped wood dry until September, which causes emission of large amounts of gases and particles into the atmosphere (Artaxo et al., 2013). Every year, from September to November, large plumes of smoke can be easily observed by satellite images (Andreae, 2009).

The analysis of the absorption and scattering of aerosols was complemented by evaluating their refractive indexes. This optical property is a mathematical function belonging to the complex numbers and has two components: the real part, "n", associated with scattering component of the aerosols, and the imaginary part, "k", associated with absorption. The 

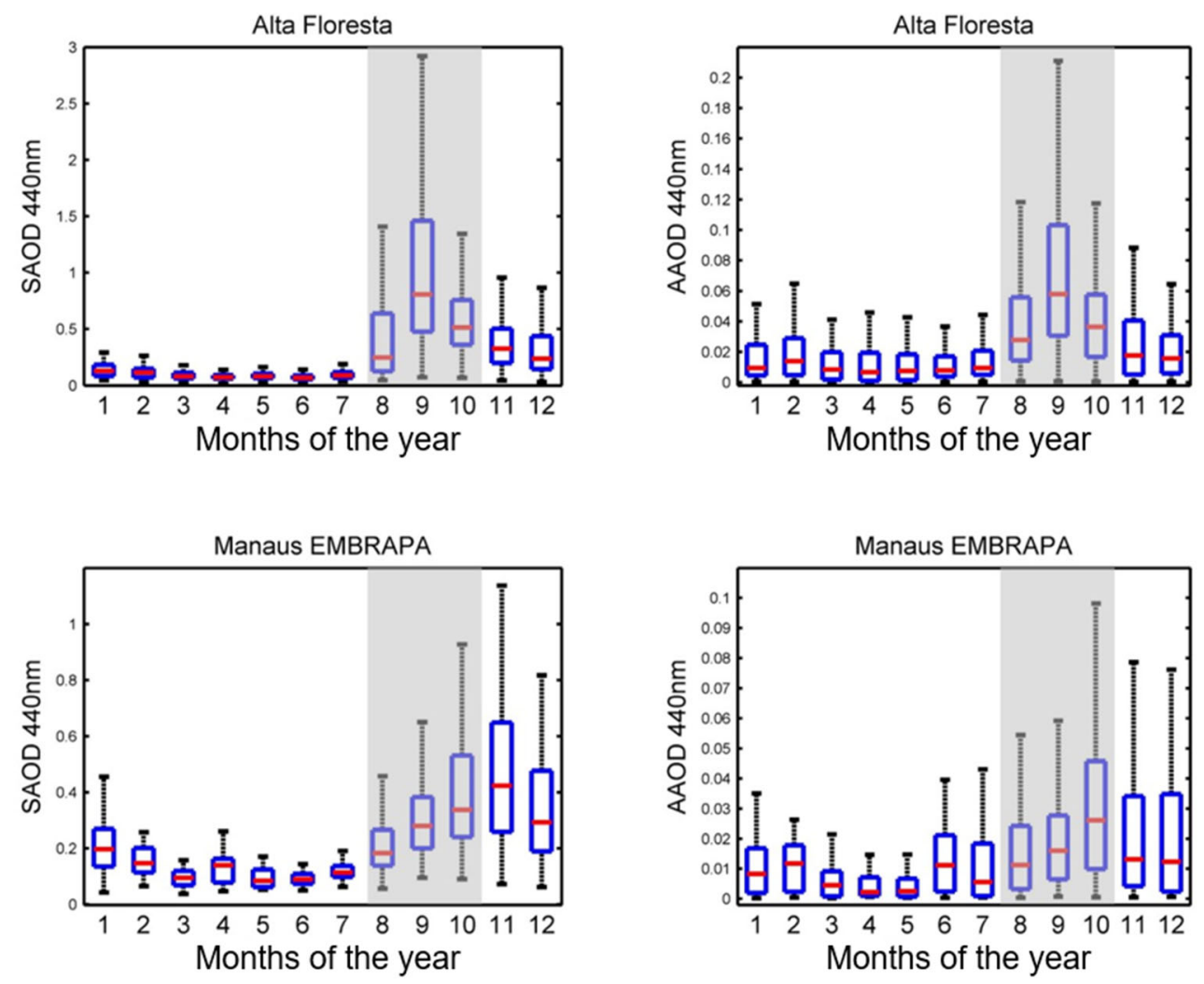

Fig. 4. Monthly variation of SAOD and AAOD for the Alta Floresta and Manaus EMBRAPA sites.

real part of the index provides, therefore, information regarding the ability to spread radiation in a given medium, while the imaginary part is directly related to how it dissipates as the material penetrates. Fig. 5 shows the spectral dependence of the refractive index for all analyzed sites. It is observed that the real component practically does not vary with the wavelength in the wet season, that is, the aerosols spread radiation at the studied wavelengths of isotropic form. The sites with most spread properties are Cuiabá, Alta Floresta, and Campo Grande, followed by the other regions of the arc of deforestation (Ji Paraná, Abracos Hill, and Rio Branco). The less scatter sites are concentrated in the central region of Amazonia (Manaus EMBRAPA, ATTO, and Manacapuru). During the dry season, a small dependence of the real part with the wavelength is observed, where the maximum values were reached at $870 \mathrm{~nm}$, a fact explained by the great variety of aerosols added in the atmosphere as products of fires.

The imaginary part of the refractive index (Fig. 5) shows two main results: the absorption of radiation is more efficient in the rainy season, the period where the index practically does not vary with the wavelength; the absorption during the dry season in Cuiabá exceeds the absorptions of the other sites, even those that are in the region of the Deforestation Arc. The lowest absorptions for both the dry season and the wet season are found in the regions of central Amazonia. Absorption and scattering analysis in the dry and wet seasons were further complemented by the evaluation of the single scattering albedo (SSA), seen in Fig. 6.

For the sites of Manaus EMBRAPA and ATTO the values of SSA at $440 \mathrm{~nm}$ practically did not vary from the dry season to the wet season, in Manaus EMBRAPA the average values of SSA at $440 \mathrm{~nm}$ were $0.93 \pm 0.06$ and $0.93 \pm 0.07$, and for ATTO $0.91 \pm 0.04$ and $0.92 \pm 0.05$, respectively for the dry and wet seasons. For the Manacapuru site, there was also no variation between the dry and wet seasons, however, the mean values of $0.88 \pm 0.04$ and $0.87 \pm 0.08$ for the dry and wet seasons respectively show that the particles in this site are more absorbent than those found in the sites of EMBRAPA and ATTO. In the sites located in the arc of deforestation (Alta Floresta, Ji Paraná, Rio Branco, and Abracos Hill) a small reduction in albedo values were observed in the wet season. In Ji Paraná for example, the mean SSA $440 \mathrm{~nm}$ was $0.92 \pm 0.03$ in the dry season and $0.86 \pm 0.08$ in the wet season. This fact evidences the predominance of the scattering during the dry season and a reduction of the scattering accompanied by the increase of the absorption during the wet season. The Cuiabá site, unlike the others, presented low values of SSA $440 \mathrm{~nm}$ even for the dry season. The average values were $0.85 \pm 0.09$ and $0.81 \pm 0.14$ (dry and wet, respectively). This result is consistent with previous analyses related to AAOD, SAOD, and complex refractive indices. However, the site of Campo Grande also did not show variations between dry and wet seasons, however, the values observed for SSA $440 \mathrm{~nm}$ were close to those found in the region of the Deforestation Arc in the wet season.

The strong increase in aerosol concentrations is still accompanied by a change in particle size distribution. The majority of the particles emitted during the burning events belong to fine-mode aerosol (Schafer et al., 2008), in addition to this, the size distribution varies radically in regions highly 

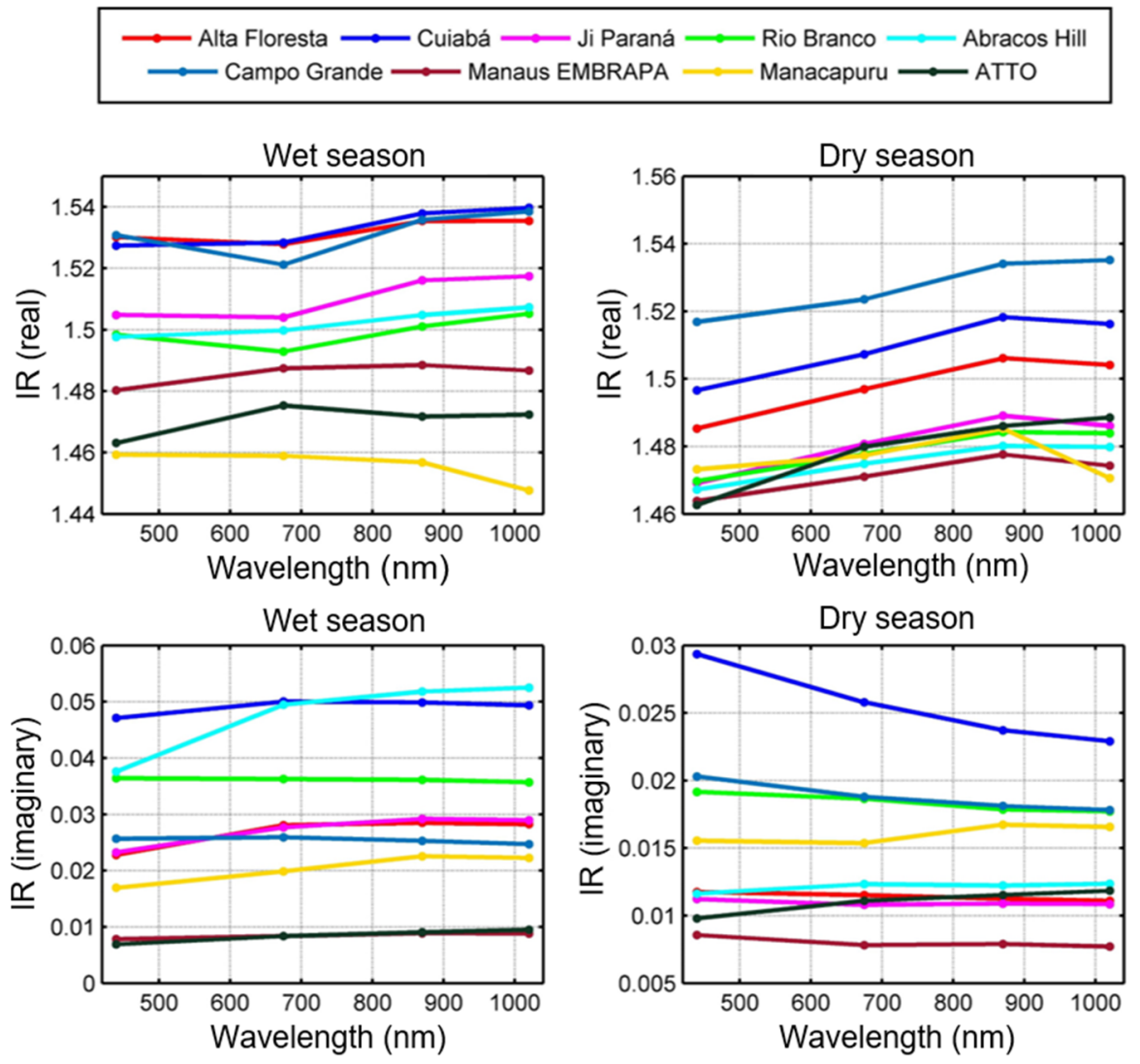

Fig. 5. Spectral dependence of the real and imaginary refractive index for the dry and wet seasons of each site.
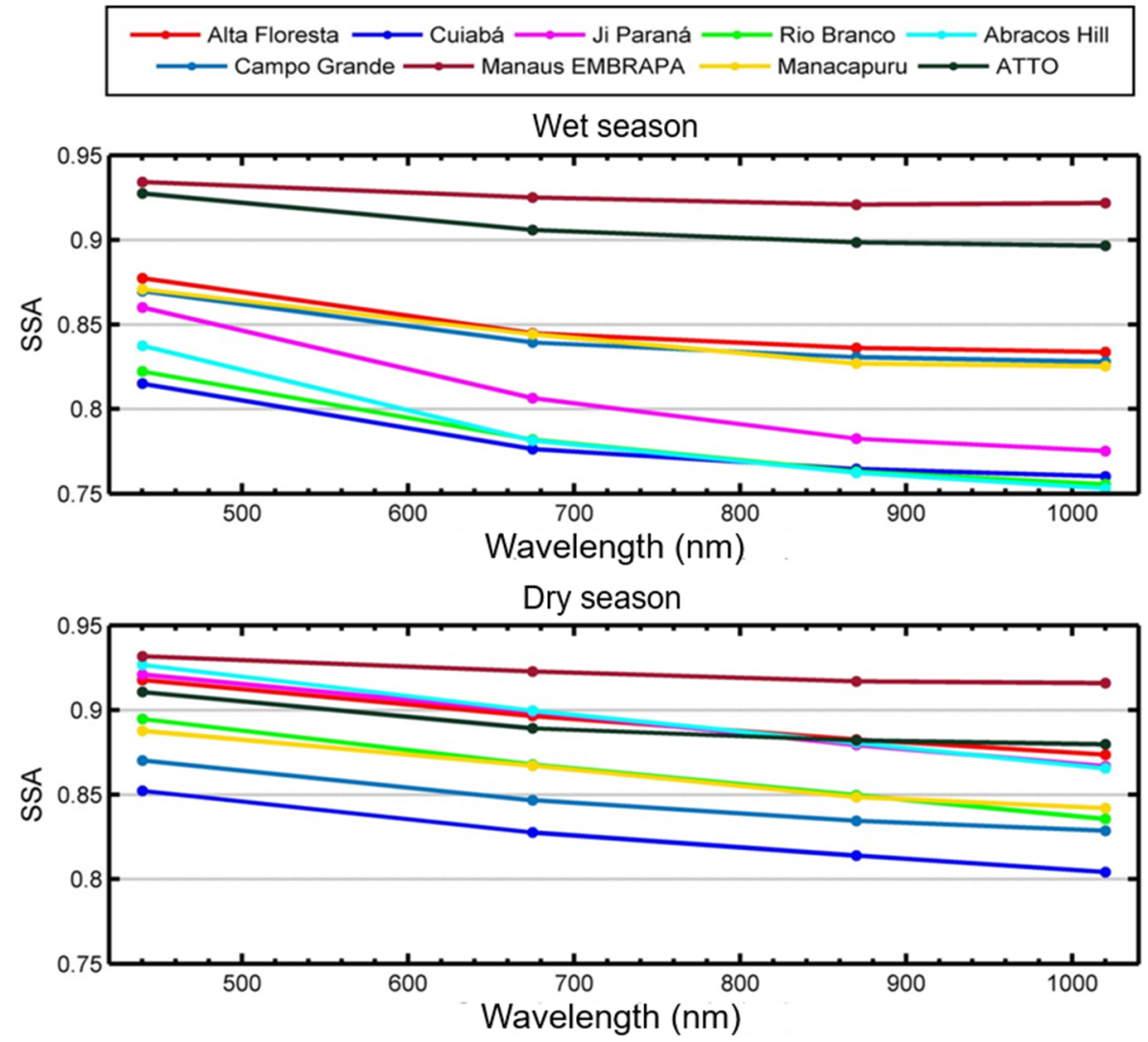

Fig. 6. Spectral dependence of the SSA for the dry and wet seasons of each site. 
influenced by biomass burning in the dry season (Eck et al., 2010). Fig. 7 shows the mean values for the entire available period of each site of the size distributions, where clearly all sites have a bimodal distribution. The average volumetric radius for fine-mode particles is approximately $0.15 \mu \mathrm{m}$ for all sites. For coarse-mode, the average volumetric radius varies between 5.0 and $6.0 \mu \mathrm{m}$ depending on the site analyzed. Although the values of the mean volumetric radius are close in practically all sites, the volumetric concentration differs significantly, it is observed that the highest concentrations of fine-mode particles are recorded in the arc of deforestation sites, Abracos Hill, Ji Paraná, Alta Floresta, and Rio Branco. For the coarse fraction, the highest concentrations are obtained for the sites belonging to central Amazonia, Manacapuru and Manaus EMBRAPA.

The analysis of the size distribution is complemented by Fig. 8, which presents the average of the distributions for the dry and wet seasons for the Alta Floresta, Cuiabá, Manacapuru and Manaus EMBRAPA sites. The high concentrations of particles belonging to the fine-mode are reached during the dry season, while the concentration of coarse-mode is more evident in the wet season. The emission by fires in the arc of deforestation explains the high concentrations of particles in the fine-mode for Alta Floresta in the dry season, while in the rainy season the local impacts and the biogenic emission may be the major responsibility for the distribution of coarse-mode.

Cuiabá presents a lower volumetric concentration than the values found for Alta Floresta and the other sites of the arc of deforestation, the optical properties for this region showed a more absorptive type of aerosol, which will be better investigated through analysis of the $\mathrm{OC}$ and $\mathrm{EC}$ fractions in this region. The size distribution found in Campo Grande did not show significant variation between the dry and wet seasons, suggesting that although this site has the same characteristics typical of the Cerrado of Cuiabá, it is less impacted by the aerosols of fires in the dry season.

\section{Classification Guideline for Aerosols}

The scatter plots between the scattering Angstrom exponent (SAE) and the absorption Angstrom exponent (AAE), the so-called Angstrom matrix, provide indications of the possible sources for the aerosols since the SAE allows a separation of the fine and coarse fractions of the particles and the AAE allows the evaluation of its absorptive properties. Fig. 9 shows the result of the methodology quoted above for the Ji Paraná site. In the wet season, the aerosols were classified as biogenic particles (BG), and the low values for SAE indicate the predominance of coarse particles. In the dry season, the emissions of OC and EC, biomass burning, overlap the biogenic particles by raising the fraction of fine particles. The separation of the OC and $\mathrm{EC}$ fractions is given on the basis of the AAE values because the EC is a highly efficient absorber at all wavelengths when compared to the OC, which absorbs only at low wavelength values (Bahadur et al., 2012).

For Ji Paraná, as well as for practically all the sites located in the arc of deforestation, during the dry season, in addition to the $\mathrm{OC}$ and $\mathrm{EC}$ classifications, a large fraction of the aerosols were classified as a mixture between OC-EC. When comparing the dry season with the wet season, it is noted that the mixture between $\mathrm{OC}$ and $\mathrm{EC}$, with isolated records of $\mathrm{OC}$, dominates the great contribution of the biomass burning. The work of Brito et al. (2014) observed that, on the Amazon, OC represents $82 \%$ of the ultrafine material, and thermal combustion analysis showed that the OC represents the dominant fraction of aerosol derived from biomass burning, with 84\% (Mayol-Bracero, 2002).

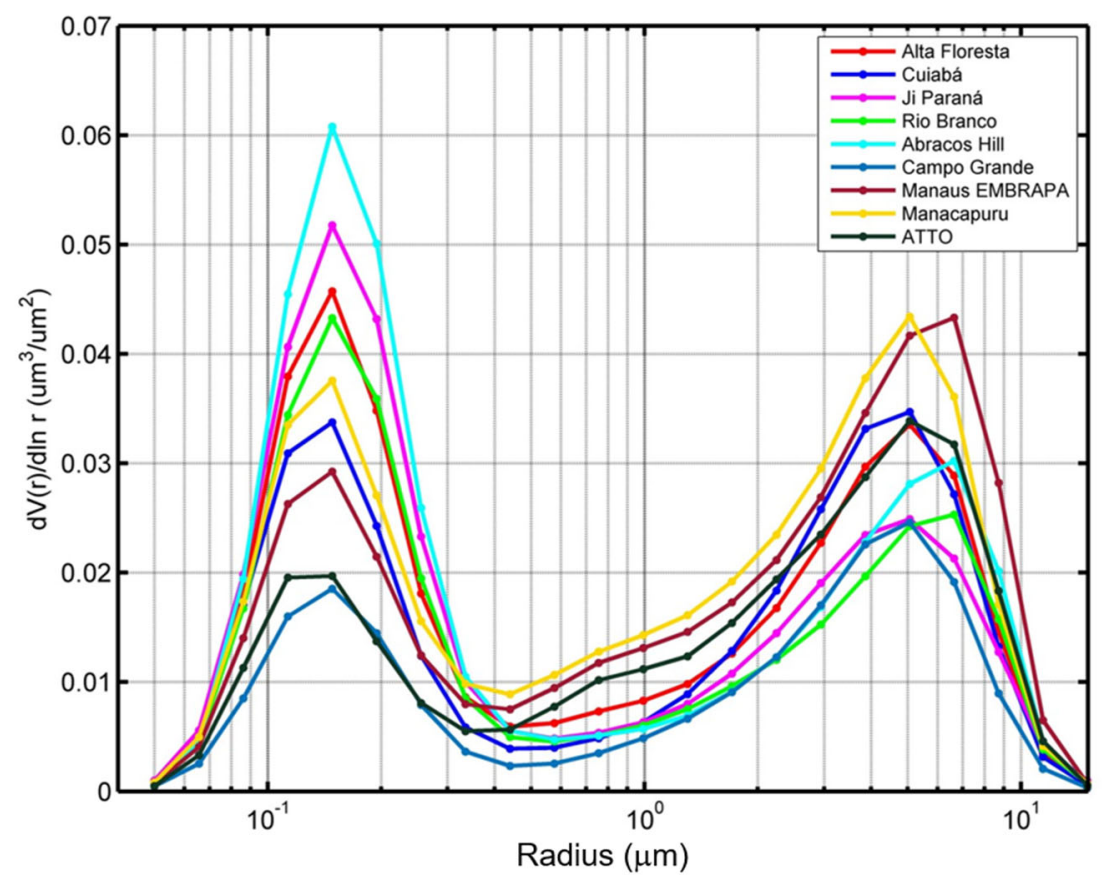

Fig. 7. Mean for size distribution volumetric values for all analyzed sites. 

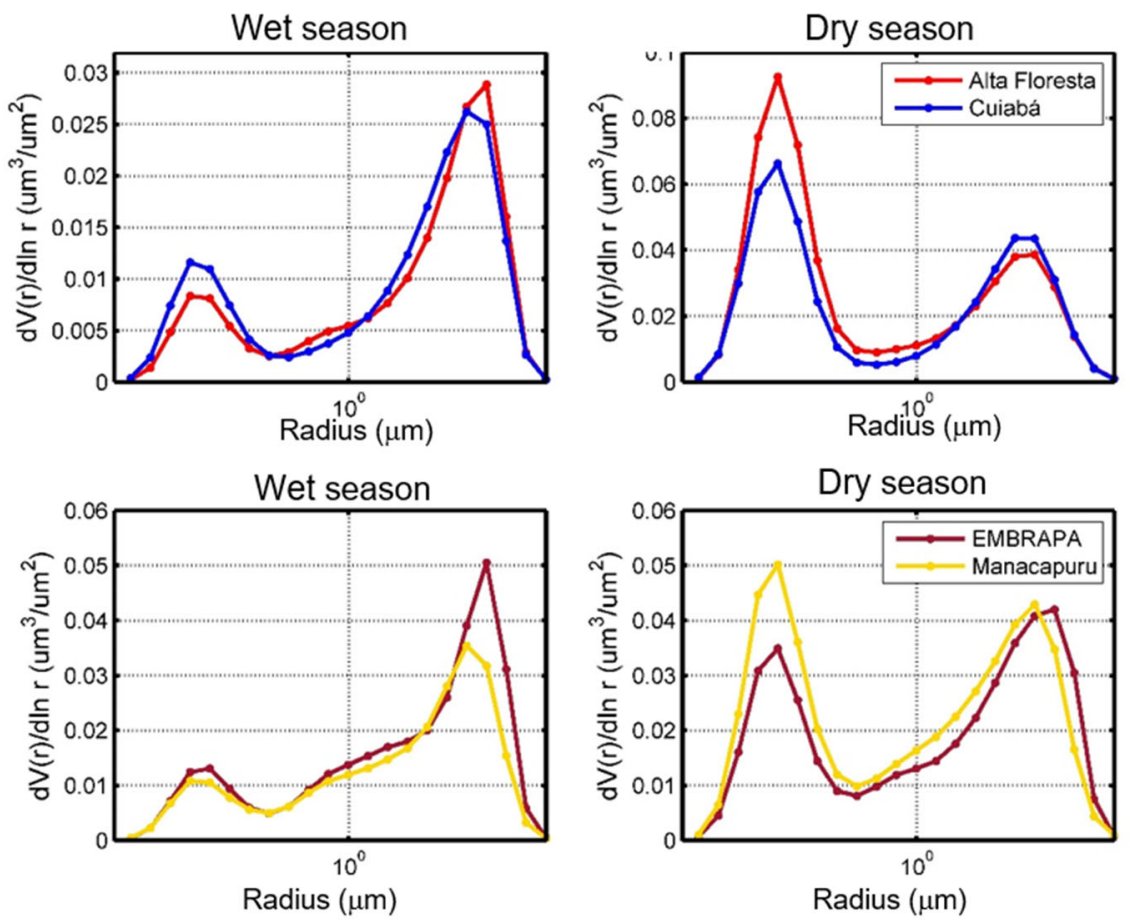

Fig. 8. Mean size distribution for the dry and wet seasons for the Alta Floresta, Cuiabá, Manacapuru and Manaus EMBRAPA sites.

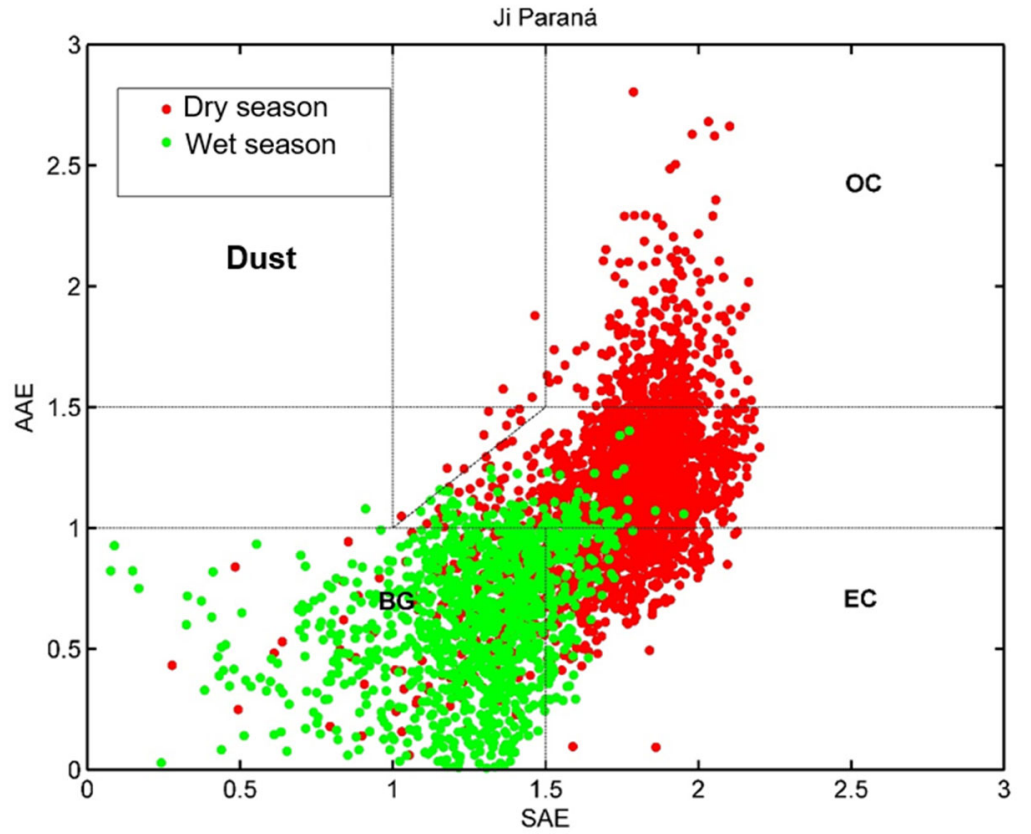

Fig. 9. Matrix of Angstrom for the dry and wet seasons in the site of Ji Paraná.

The same methodology was applied to all the AERONET sites used in this work. The dry season in Alta Floresta evidenced a mixed composition of a series of particulate material being possible to verify through the Angstrom matrix with large distributions of the fractions of EC and OC in the region. The vast variability over the Alta Floresta during the dry season can be explained by the addition of biomass burning particles from the local forests and by the addition of particulate material from pasture and Cerrado fires carried to the site through transport in the atmosphere. Because of the high concentration of fine particles in the dry season, Rizzo et al. (2013) states that the dispersion of radiation in the Amazon Basin is substantially influenced, changing abruptly in the wet season due to the great removal of this material by precipitation.

For the Rio Branco site, the behavior of the SAE and AAE 
distribution was similar to that found in Alta Floresta. The Angstrom matrix showed a predominance of coarse particles in the wet season and fine in the dry season, a fact also explained by the chemical variations of the biomass burning emissions in the Amazon Basin (Artaxo et al., 2013; Brito et al., 2014). For the Cuiabá site, the distribution of the Angstrom matrix showed similar behavior to the sites located in the Amazonian biome, evidencing the predominance of coarse particles during the wet season. This may be associated with urban emissions and soil dust suspension since the site is located in an area near the urbanized region of the capital Cuiabá in the state of Mato Grosso. In the location of the CIMEL radiometer, the present vegetation is low and typical of the Cerrado, so that, over this region, the biogenic contributions are somewhat limited. In the dry season, the influence of the fires was clearly detected due to the large distribution of points on the Angstrom matrix in the fraction of $\mathrm{OC}$ and $\mathrm{EC}$, as well as by the mixture between these two classifications. Through the analysis of the values obtained for SAE, we can see a small reduction when compared to the sites of Alta Floresta and Rio Branco. Such reduction suggests a small increase of the particles in the dry season when compared to the sites located to the north, in the Amazon biome.

The small difference detected in particle size between Cuiabá, Alta Floresta, and Rio Branco may be associated, besides the form of combustion that occurred in the burning process, to the process of transporting these particles of fires over the regions located in the Cerrado. For the Campo
Grande site, as discussed by Hoelzemann et al. (2009), industrial urban influences predominate over the wet season. In the dry season, the largest contributions are due to biomass burning. For Campo Grande, the fraction of the dispersion in the Angstrom matrix for the rainy season is in a transition band between $\mathrm{OC}$ and $\mathrm{EC}$, which strongly characterizes the emission of fossil fuel combustion, vehicular and urban emission. The quantification of the types of aerosols classified in the dry and wet season is presented in percentages in Table 3 and 4, respectively.

Its observed for the sites of Ji Paraná, Rio Branco, and Abracos Hill that the sum between OC-EC and OC blend fractions exceeds $60 \%$, this also occurs for Alta Floresta and Cuiabá. For sites located in central Amazonia, the values found for the OC are extremely low, however, records for biogenic particles remain high, reaching $67.97 \%$ BG in the ATTO site. Table 4 represents the quantification for the types of aerosols in the rainy season, and Table 3 can be analyzed in parallel to evaluate the changes of the constituents according to the period of drought or rain. In Alta Floresta and Ji Paraná, they have similar or even larger biogenic aerosol fractions than the values found in central Amazonia, which is also true for the Cuiabá and Campo Grande sites. For the ATTO site, there is practically no variation for BG fraction between dry and wet seasons, however, the OC-EC blend fraction is reduced from 27 to $16 \%$. For Manacapuru this reduction was even more evident, from 43 to $23 \%$. In the wet season, it was still possible to visualize a small fraction $(1.48 \%)$ of mineral dust on the site of Manaus EMBRAPA.

Table 3. Quantification of the types of aerosols (for dry season) on the AERONET sites used in this study, (BG: Biogenic), (EC: Elementary Carbon), (OC: Organic Carbon), (OC-EC: Mixture of OC and EC).

\begin{tabular}{lllll}
\hline & \multicolumn{5}{c}{ Dry season } \\
\hline Site & BG $(\%)$ & EC $(\%)$ & OC $(\%)$ & OC-EC $(\%)$ \\
\hline ATTO & 67.97 & 4.49 & -- & 27.52 \\
Manaus E. & 38.74 & 4.45 & 0.68 & 53.37 \\
Manacapuru & 45.45 & 8.78 & 2.51 & 42.63 \\
Alta Floresta & 23.77 & 11.97 & 15.13 & 49.48 \\
Ji Paraná & 11.38 & 21.00 & 12.81 & 54.67 \\
Rio Branco & 8.77 & 14.12 & 10.04 & 66.88 \\
Abracos Hill & 5.82 & 26.54 & 18.78 & 48.85 \\
Cuiabá & 21.45 & 5.63 & 11.52 & 58.95 \\
Campo Grande & 38.35 & 6.87 & 4.11 & 48.21 \\
\hline
\end{tabular}

Table 4. Quantification of the types of aerosols (for rainy season) on the AERONET sites used in this study, (BG: Biogenics), (EC: Carbon Elementary), (OC: Organic Carbon), (OC-EC: Mixture of OC and EC), (D: Dust).

\begin{tabular}{|c|c|c|c|c|c|}
\hline \multicolumn{6}{|c|}{ Wet season } \\
\hline Site & $\mathrm{BG}(\%)$ & $\mathrm{EC}(\%)$ & $\mathrm{OC}(\%)$ & OC-EC (\%) & $\mathrm{D}(\%)$ \\
\hline ATTO & 68.51 & 14.81 & -- & 16.67 & -- \\
\hline Manaus E. & 66.17 & 1.11 & -- & 23.30 & 1.48 \\
\hline Manacapuru & 88.37 & 5.81 & -- & 5.23 & -- \\
\hline Alta Floresta & 80.57 & 4.67 & 0.12 & 14.31 & -- \\
\hline Ji Paraná & 77.73 & 13.01 & -- & 9.17 & -- \\
\hline Rio Branco & 39.63 & 14.99 & -- & 44.39 & -- \\
\hline Abracos Hill & 54.96 & 22.05 & -- & 22.97 & -- \\
\hline Cuiabá & 75.41 & 3.28 & 0.42 & 19.67 & -- \\
\hline Campo Grande & 67.51 & 13.65 & -- & 17.69 & -- \\
\hline
\end{tabular}


Mineral dust detection events in the central Amazon during the rainy season are related to the long-distance transport of dust from the Sahara Desert.

During the wet season the Central Amazon sites atmosphere is extremely clean, which is explained by winds predominantly coming from the northeastern at ATTO site that crosses several kilometers over preserved forest (Andreae et al., 2012). Thereby, in that season the major contribution of aerosols is due to biogenic emissions. Eventually, during February and March, winds from Saara desert transports aerosols to the study area (Martin et al., 2016) and during the dry season the burning events add large carbon quantity to the atmosphere increasing the mixture ratio of OC-EC.

Sites located in the arc of deforestation have the composition of aerosols, in the wet season, mainly formed by $\mathrm{BG}$, emitted locally by the remaining vegetation. However, in the dry season, this region is directly impacted by local burning more than are that sites at the Central Amazon. At the Cuiabá and Campo Grande sites, the dynamics of the emission sources are completely different, since in the wet season local industrial emissions predominate, which are increased by emissions of local burning and of particulate matter from the northern during the dry season.

The long-distance transport of aerosol particles follows the same pattern of atmosphere circulation, making that Amazon forest emissions be transported to out of south American continent by pathway: the tropical Pacific and south Atlantic oceans (Freitas et al., 2000). The convective motion aids the aerosol transport by making, in certain conditions, that emissions reaches Caribbean region (Andreae et al., 2001). The aerosols are basic components in the terrestrial energy balance, although their role is still not fully understood. The so-called direct effect of aerosols on climate is consisted of mechanisms that affect the surface solar radiation flux, which can lead to both surface heating or cooling, depending on the intrinsic properties of aerosol variations and surface reflectivity.

Change in aerosol-induced solar energy flux affects the temperature profile of the atmosphere as well as the heat conserved in the oceans, cryosphere and biosphere as a whole. One of the main forms to study and evaluate the biomass burning aerosol-induced climate changes is through the future projections of the atmosphere state including this perturbation. Such a projections are obtained by physicalbased mathematical model that, to be physically consistent, needs to confident field data and suitable parametrization to treat the aerosol emissions and transport.

\section{Impacts on Radiative Fluxes}

The value of surface radiative forcing (FR-Surface) for the sites of Alta Floresta and Cuiabá in the dry season reached daily averages that exceeded $-160 \mathrm{Wm}^{-2}$. In the case of FR-Surface values, all the extinction of the radiation that does not directly affect the surface is taken into account, in this way, the values of spreading and absorption act together causing low values even for the site of Cuiabá, whose absorption stands out in relation to the other sites.

During the dry season, the FR-Surface instantaneous values were related to the optical scattering depth (SAOD $440 \mathrm{~nm}$ ), the values of SAOD $440 \mathrm{~nm}$ were still separated as a function of the OC and EC fractions. The linear adjustment, shown in Fig. 10 for the Alta Floresta site, showed that the greatest impacts on the radiative flux occurred due to the scattering related to the fraction $\mathrm{OC}$ with instantaneous maximum values that reached up to $-400 \mathrm{~W} \mathrm{~m}^{-2}$. The same behavior was observed for the Cuiabá sites with instantaneous values up to $-350 \mathrm{~W} \mathrm{~m}^{-2}$, and $-100 \mathrm{~W} \mathrm{~m}^{-2}$ for Manaus EMBRAPA.

Fig. 10 still shows a linear relationship between the scattering of the EC fraction with the FR-Surface, this event

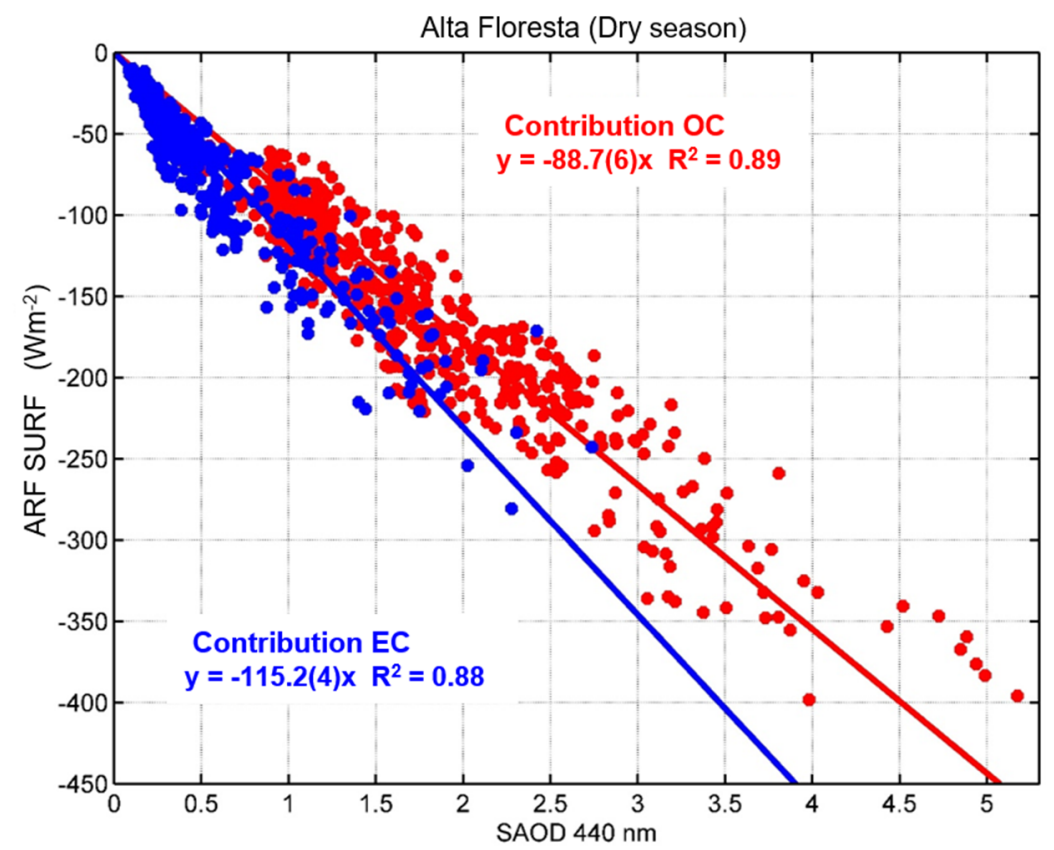

Fig. 10. Relation between FR-Surface and optical scattering depth (SAOD $440 \mathrm{~nm}$ ) for the OC and EC fractions. 
is indeed very strange, since the EC is responsible for the absorption of the radiation and not for the scattering. The explanation for this phenomenon can be attributed to a failure in the method of separation of the fractions OC and EC by the Angstrom matrix, in which biogenic particles in the fine fraction can be considered as EC. In order to evaluate the possible contributions of scattering and absorption on FR-Surface to the different regions, the radiative forcing efficiency was determined for both SAOD $440 \mathrm{~nm}$ and AAOD $440 \mathrm{~nm}$ in dry and wet seasons. Table 5 shows the values of the $\mathrm{R}^{2}$ coefficient of determination between the FR-Surface and the values of SAOD and AAOD $440 \mathrm{~nm}$ as well as the values obtained for scattering radiative forcing efficiency (EF-SAOD) and absorption radiative forcing efficiency (EF-AAOD).

By means of the values of $\mathrm{R}^{2}$, it was possible to observe that during the dry season both the scattering and the absorption have a good direct relation with FR-Surface, already in the wet season, this behavior is only observed for the absorption. An exception was observed at the site of Manaus EMBRAPA, which presented a better relationship than the one found in the dry season. The EF-SAOD values in the dry season show that the impact of scattering on the radiation flux is more evident in the forest. This is due to the increase of scattering particles (OC) by biomass burning. For Cuiabá, the competition between the OC and EC fractions, by the burning of Cerrado and pasture, makes EF-SAOD smaller than in Forest, which corroborate with previous data. The site at Manaus EMBRAPA found the lowest value of EF-SAOD was due to the lower impact of burnt aerosols on the region. The EF-AAOD values in the dry season again indicate the strong absorptive power of the aerosols on Cuiabá, whose EF-AAOD value was approximately 15\% higher than the other sites. In the wet season, the behavior of EF-AAOD was very similar to the dry season, however, it was observed that for Alta Floresta and Cuiabá the absorption effect is the majority over the radiation flux. For Manaus EMBRAPA, a competition was observed between the spreading and the absorption in the rainy season, with an $\mathrm{R}^{2}$ value of 0.79 and 0.70 for the SAOD and AAOD fractions, respectively.

\section{Effect of Biogenic Particles}

The fraction classified as biogenic aerosol showed an egalitarian dispute between absorption and scattering, where the plot influenced the FR-Surface instantaneous to $80 \mathrm{~W} \mathrm{~m}^{-2}$. The impact caused by the sum of the scattering and absorption influences of the primary biogenic particles results, on average, in approximately $-20 \mathrm{~W} \mathrm{~m}^{-2}$ FR-Surface. This value is practically the average seasonal value found for the entire rainy season $\left(-21.27 \mathrm{~W} \mathrm{~m}^{-2}\right)$. The effect of the biogenic particles on FR-surface in the central Amazonia represents up to $45 \%$ of the total effect caused by the aerosols, comparing this value with the mean of the FR-Surface in the dry season $\left(-41.05 \mathrm{~W} \mathrm{~m}^{-2}\right)$.

The results show that biogenic aerosols are responsible for both absorption and scattering. Thus, any simulation or even radiative forcing modeling that assesses the impact of burnt aerosols on the Amazon should take into account the interaction of the radiation with these "background particles". To quantify the effect of biogenic aerosols on the climate, the values of AOD $500 \mathrm{~nm}$ (AERONET) for Manaus EMBRAPA in the rainy season were still applied to the dynamic model proposed by Procópio et al. (2003), thus determining the values of FR-Top 24 hours, as seen in Fig. 11.

Fig. 11 represents the annual FR-Top statistics 24 hours, considering only the wet season. It is observed that in general, the effect of the biogenic particles cools the climatic system, however, the magnitude of the values of FR-Top $24 \mathrm{hr}$ makes it clear that these particles influence very little on the climate. Some estimates of FR-Top $24 \mathrm{hr}$ for Amazonia quantify the effect, for the whole period (dry and wet), on values ranging from -5.2 to $-8.2 \mathrm{~W} \mathrm{~m}^{-2}$ (Procópio et al., 2004; Sena et al., 2013; Sena and Artaxo, 2015), that is, the biogenic component represents only about $7 \%$ of the effect of aerosols on the climate. It was also observed that the mean values of FR-Top 24 for the years 2012, 2014, 2015 and 2016 are very similar, however, in the years 2010 and 2013 the averages reached positive values, evidencing the dispute between the processes of scattering and absorption of the biogenic particles on the direct radiation flux. The uncertainties related to the years with negative averages are higher, evidencing the difficulty of quantifying the spreading effect for the biogenic particles.

\section{SUMMARY AND CONCLUSIONS}

With long-term measurements of the optical properties of aerosols, it was possible to conclude that the values of AOD $500 \mathrm{~nm}$, which remained in a reduction trend from 2010 to

Table 5. Regression adjustments performed between FR-Surface and values of SAOD $440 \mathrm{~nm}$ and AAOD $440 \mathrm{~nm}$, $\mathrm{R}^{2}$ values and radiative forcing (EF) efficiency for SAOD and AAOD.

\begin{tabular}{|c|c|c|c|c|}
\hline \multicolumn{5}{|c|}{ Dry season } \\
\hline Site & $\mathrm{R}^{2}$ & EF-SAOD (W m $\left.{ }^{-2} / \mathrm{SAOD} 440 \mathrm{~nm}\right)$ & $\mathrm{R}^{2}$ & EF-AAOD (W m²/AAOD 44 0nm) \\
\hline Alta Floresta & 0.89 & -89.65 & 0.80 & -1196.40 \\
\hline Cuiabá & 0.73 & -94.37 & 0.79 & -869.00 \\
\hline Manaus E. & 0.69 & -106.86 & 0.60 & -1015.30 \\
\hline \multicolumn{5}{|c|}{ Wet season } \\
\hline Site & $\mathrm{R}^{2}$ & EF-SAOD (W m $\left.{ }^{-2} / \mathrm{SAOD} 440 \mathrm{~nm}\right)$ & $\mathrm{R}^{2}$ & EF-AAOD (W m²/AAOD $440 \mathrm{~nm})$ \\
\hline Alta Floresta & 0.57 & -133.10 & 0.80 & -1040.30 \\
\hline Cuiabá & 0.26 & -121.43 & 0.88 & -805.59 \\
\hline Manaus E. & 0.79 & -122.56 & 0.70 & -1196.80 \\
\hline
\end{tabular}




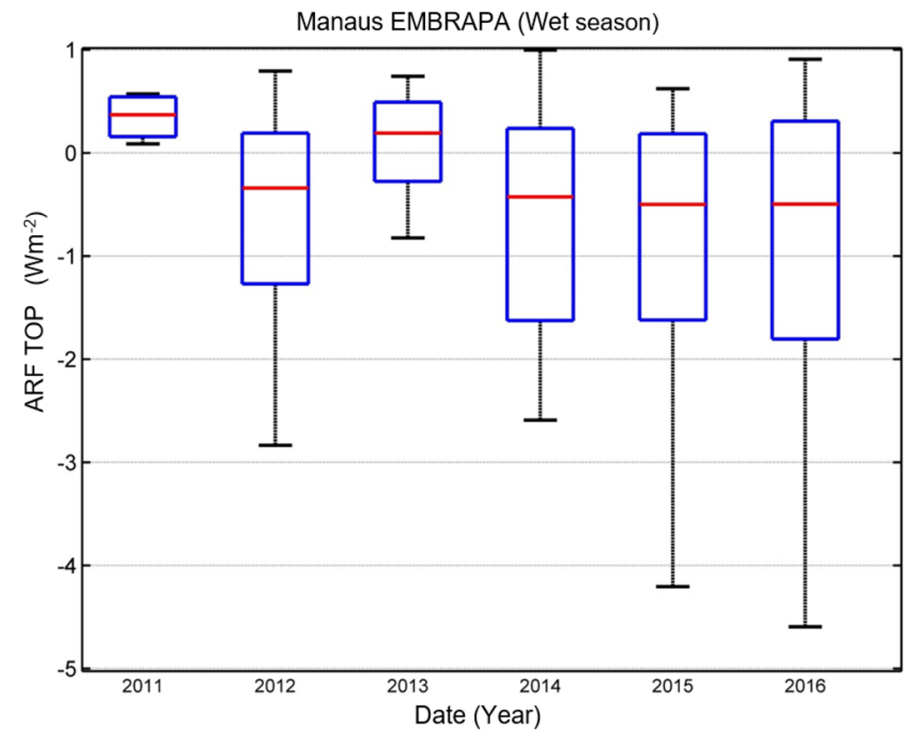

Fig. 11. Annual statistics for the values of FR-Top 24 hours, for the rainy season in the site of Manaus EMBRAPA.

2012, returned to an increasing trend from the year 2013. The time series of AOD $500 \mathrm{~nm}$ found that the analyzed sites showed a clear seasonal variation, with the maximum reached during the dry season, due to biomass burning. The increasing trend of the maximum value of AOD $500 \mathrm{~nm}$ accompanies the increase of deforestation rates in the legal Amazon, which was approximately $5000 \mathrm{~km}^{2}$ to $8000 \mathrm{~km}^{2}$ per year from 2014 to 2016 (Supplementary material). The time series still showed that the sites present in the central Amazon area impacted as the others, the Manaus EMBRAPA website, for example, reached values of $2.5 \mathrm{~nm}$ AOD of $2.5 \mathrm{in}$ the dry season of 2015, a figure higher than the maximum found on Rio Branco, which is directly affected by deforestation arc burning emissions.

Comparing the values of AOD $500 \mathrm{~nm}$ between the sites of ATTO and Manaus EMBRAPA can be verified that for low AOD values. The characteristics of the aerosols are similar, however, for high values of AOD $500 \mathrm{~nm}$, the site of Manaus EMBRAPA is more impacted, i.e. under the influence of aerosols of fires the values of AOD $500 \mathrm{~nm}$ is higher on Manaus EMBRAPA. Through the analysis of the absorptive properties in the atmospheric column, it was possible to verify that the use and occupation of the soil interfere scattering in the absorption processes. Based on the analysis of AAOD, SAOD, refractive indices (real and complex) and (SSA), it was observed that in the dry season the sites of central Amazonia had the lowest values of scattering and absorption, while the sites belonging to the Deforestation Arc presented high values of scattering and absorption in the dry season.

The optical properties for the Cuiabá site stood out in the absorption during the dry season, all analyzed variables indicated the same result, that the aerosol in Cuiabá is more absorptive than in other regions. For the sites in central Amazonia, the values of SSA $440 \mathrm{~nm}$ practically did not vary from the dry season to the rainy season, in Manaus EMBRAPA, for example, the mean SSA $440 \mathrm{~nm}$ values for the dry and wet seasons were $0.93 \pm 0.06$ and $0.93 \pm 0.07$, respectively.
The spectral analysis verified that the fraction of biogenic particles goes from approximately 38 to $67 \%$ in the site of Manaus EMBRAPA, for ATTO, this fraction remains practically constant throughout the year, around $68 \%$, since the OC-EC blend fraction increased from approximately $16 \%$ to $27 \%$. OC fractions increased in all sites in the dry season, also because of biomass burning emissions, for Alta Floresta, for example, the fraction of OC 0.12 to $12.81 \%$. It was found that in the central Amazon, in the dry season, the OC fraction generates instantaneous effects of up to $-100 \mathrm{Wm}^{-2}$ in the radiative surface forcing (FR-Surface), while in the Cerrado region (Cuiabá) the instantaneous values reached up to $-350 \mathrm{Wm}^{-2}$. The impact of the primary biogenic particles on the radiative flux resulted in an average of approximately $-20 \mathrm{Wm}^{-2}$ FR-Surface, representing $45 \%$ of the total effect caused by aerosols in the Amazon. In Cuiabá, in the Cerrado, unlike the others, presented low values of SSA $440 \mathrm{~nm}$ even for the dry season, the mean was $0.85 \pm 0.09$ and $0.81 \pm 0.14$ (dry and wet, respectively).

\section{ACKNOWLEDGMENTS}

The authors thank CAPES for the financial support (Process $n^{\circ}$ 01439213127) and the research group of the Graduate Program in Environmental Physics (Project of 457824/2013-1 approved process in call $\mathrm{n}^{\circ} 68 / 2013 \mathrm{MCTI} / \mathrm{CNPq} / \mathrm{FNDCT}-$ Cross action/LBA). The research group of the Institute of Physics of the University of São Paulo (USP) for the availability of the AERONET network data. The authors wish to acknowledge a significant contribution from NASA to provide AERONET data (http://aeronet.gsfc.nasa.gov/). We thank the scientists and technicians responsible for operating and maintaining the instrumentation over the course of many years that generated this high-quality data set and ultimately enabled this paper to be written. The researcher Paulo Artaxo and his group from the Atmospheric Physics laboratory of the University of São Paulo (USP). 


\section{REFERENCES}

Andreae, M.O., Artaxo, P., Fischer, H. and Freitas, S.R. (2001). Transport of biomass burning smoke to the upper troposphere by deep convection in the equatorial region. Geophys. Res. Lett. 28: 951-954.

Andreae, M.O. (2009). Correlation between cloud condensation nuclei concentration and aerosol optical thickness in remote and polluted regions. Atmos. Chem. Phys. 9: 543-556. doi: 10.5194/acp-9-543-2009.

Andreae, M.O., Artaxo, P., Beck, V., Bela, M., Freitas, S., Gerbig, C., Longo, K., Munger, J.W., Wiedemann, K.T. and Wofsy, S.C. (2012). Carbon monoxide and related trace gases and aerosols over the Amazon Basin during the wet and dry seasons, Atmos. Chem. Phys. 12: 60416065. doi: 10.5194/acp-12-6041-2012.

Andreae, M.O., Acevedo, O.C., Araùjo, A., Artaxo, P., Barbosa, C.G.G., Barbosa, H.M.J., Brito, J., Carbone, S., et al. (2015). The Amazon Tall Tower Observatory (ATTO): Overview of pilot measurements on ecosystem ecology, meteorology, trace gases, and aerosol. Atmos. Chem. Phys. 15: 0723-10776. doi: 10.5194/acp-15-107232015.

Arneth, A., Harrison, S.P., Zaehle, S., Tsigaridis, K., Menon, S., Bartlein, P.J., Feichter, J., Korhola, A., Kulmala, M., O'Donnell, D., Schurgers, G., Sorvari, S. and Vesala, T. (2010). Terrestrial biogeochemical feedbacks in the climate system. Nat. Geosci. 3: 525-532. doi: 10.1038/ngeo905.

Artaxo, P., Rizzo, L.V., Brito, J.F., Barbosa, H.M.J., Arana, A., Sena, E.T., Cirino, G.G., Bastos, W., Martin, S.T. and Andreae, M.O. (2013). Atmospheric aerosols in Amazonia and land use change: From natural biogenic to biomass burning conditions. Faraday Discuss. 165: 203-235. doi: 10.1039/C3FD00052D.

Bahadur, R., Praveen, P.S., Xu, Y. and Ramanathan, V. (2012). Solar absorption by elemental and brown carbon determined from spectral observations. PNAS 109: 1736617371. doi: 10.1073/pnas.1205910109.

Barbosa, H., Barja, B.C., Pauliquevis, T., Gouveia, D., Artaxo, P., Cirino, G., Santos, R.M. and Oliveira, A.B. (2014). A permanent Raman lidar station in the Amazon: description, characterization, and first results. Atmos. Meas. Tech. 7: 1745-1762. doi: 10.5194/amt-7-17452014.

Bergstrom, R.W., Russell, P.B. and Hignett, P.B. (2002). Wavelength dependence of the absorption of black carbon particles: Predictions and results from the TARFOX experiment and implications for the aerosol single scattering albedo. J. Atmos. Sci. 59: 567-577. doi: 10.1175/15200469(2002)059<0567:WDOTAO>2.0.CO;2.

Brito, J., Rizzo, L.V., Morgan, W.T., Coe, H., Johnson, B., Haywood, J., Longo, K., Freitas, S., Andreae, M.O. and Artaxo, P. (2014). Ground-based aerosol characterization during the South American Biomass Burning Analysis (SAMBBA) field experiment. Atmos. Chem. Phys. 14: 12069-12083. doi: 10.5194/acp-14-12069-2014.

Carslaw, K.S., Boucher, O., Spracklen, D.V., Mann, G.W., Rae, J.G.L., Woodward, S. and Kulmala, M. (2010). A review of natural aerosol interactions and feedbacks within the Earth system. Atmos. Chem. Phys. 10: 17011737. doi: 10.5194/acp-10-1701-2010.

Eck, T.F., Holben, B.N., Reid, JS., Dubovik, A., Smirnov, O.T.O.N.N., Slutsker, I. and Kinne, S. (1999). Wavelength dependence of the optical depth of biomass burning, urban, and desert dust aerosols. J. Geophys. Res. 104: 00093-00095. doi: 10.1029/1999JD900923.

Eck, T.F., Holben, B., Sinyuk, A., Pinker, R., Goloub, P., Chen, H., Chatenet, B., Li, Z., Singh, R.P. and Tripathi, S.N. (2010). Climatological aspects of the optical properties of fine/coarse mode aerosol mixtures. J. Geophys. Res. 115: D19205. http://dx.doi.org/10.1029/2010JD014002.

Freitas, S.R., Silva Dias, M.A.F., Silva Dias, L.L., Longo, K.M., Artaxo, P., Andreae, M.O. and FISCHER, H. (2000). A convective kinematic trajectory technique for low resolution atmospheric models. J. Geophys. Res. 105: 24375-24386. doi: 10.1029/2000JD900217.

Fuzzi, S., Decesari, S., Facchini, M.C., Cavalli, F., Emblico, L., Mircea, M., Andreae, M.O., Trebs, I., et al. (2007). Overview of the inorganic and organic composition of size-segregated aerosol in Rondônia, Brazil, from the biomass-burning period to the onset of the wet season. $J$. Geophys. Res. 112: D01201. doi: 10.1029/2005JD006741.

Hallquist, M., Wenger, J.C., Baltensperger, U., Rudich, Y., Simpson, D., Claeys, M., Dommen, J., Donahue, N.M., George, C., Goldstein, A.H., Hamilton, J.F., Herrmann, H., Hoffmann, T., Iinuma, Y., Jang, M., Jenkin, M.E., Jimenez, J.L., Kiendler-Scharr, A., Maenhaut, W., McFiggans, G., Mentel, Th.F., Monod, A., Prévôt, A.S. H., Seinfeld, J.H., Surratt, J.D., Szmigielski, R. and Wildt, J. (2009). The formation, properties and impact of secondary organic aerosol: Current and emerging issues. Atmos. Chem. Phys. 9: 5155-5236. doi: 10.5194/acp-9-5155-2009.

Hansen, M.C., Potapov, P.V., Moore, R., Hancher, M., Turubanova, S.A., Tyukavina, A., Thau, D., Stehman, S.P., Goetz, S.J., Loveland, T.R., Kommareddy, A., Egorov, A., Chini, L., Justice, C.O. and Townshend, J.R.G. (2013). High-Resolution global maps of 21st-century forest cover change. Science 342: 850-853. doi: 10.1126/science. 1244 693.

Hoelzemann, J.J., Longo, K.M., Fonseca, R.M., Rosário, N.M. E., Elbern, H., Freitas, S.R. and Pires, C. (2009). Regional representativity of AERONET observation sites during the biomass burning season in South America determined by correlation studies with MODIS Aerosol Optical Depth. J. Geophys. Res. 114: D13301. doi: 10.1029/2008JD010369.

Holben, B.N., Eck, T.F., Slutsker, I., Tanré, D., Buis, J.P., Setzer, A., Vermote, E., Reagan, J.A., Kaufman, Y.J., Nakajima, T., Lavenu, F., Jankowiak, L. and Smirnov, A. (1998). A federated instrument network and data archive for aerosol characterization. Remote Sens. Environ. 66: 116. doi: 10.1016/S0034-4257(98)00031-5.

INPE - Instituto Nacional de Pesquisas Espaciais (2018). Portal do Monitoramento de Queimadas e Incêndios (http://www.inpe.br/queimadas). Access: 22 May 2018.

Kirchstetter, T.W., Novakov, T. and Hobbs, P. (2004) Evidence that the spectral dependence of light absorption by aerosols is affected by organic carbon. J. Geophys. 
Res. 109: D21208. doi: 10.1029/2004JD004999.

Marengo, J.A., Nobre, C.A., Tomasella, J., Cardoso, M.F. and Oyama, M.D. (2008). Hydro-climatic and ecological behaviour of the drought of Amazonia in 2005. Philos. Trans. R. Soc. London, Ser. B 363: 1773-1778. doi: 10.1098/rstb.2007.0015.

Marengo, J.A., Tomasella, J., Alves, L.M., Soares, W.R. and Rodriguez, D.A. (2011). The drought of 2010 in the context of historical droughts in the Amazon region. Geophys. Res. Lett. 38: L12703. doi: 10.1029/2011GL047436.

Martin, S.T., Artaxo, P., Machado, L.A.T., Manzi, A.O., Souza, R.A.F., Schumacher, C., Wang, J., Andreae, M.O., Barbosa, H.M.J., Fan, J., Fisch, G., Goldstein, A.H., Guenther, A., Jimenez, J.L., Pöschl, U., Silva Dias, M.A., Smith, J.N. and Wendisch, M. (2016). Introduction: Observations and Modeling of the Green Ocean Amazon (GoAmazon2014/5). Atmos. Chem. Phys. 16: 4785-4797. doi: 10.5194/acp-16-4785-2016.

Mayol-Bracero, O.L., Guyon, P., Graham, B., Roberts, G., Andreae, M.O., Decesari, S., Facchini, M.C., Fuzzi, S. and Artaxo, P. (2002). Water-soluble organic compounds in biomass burning aerosols over Amazonia 2. Apportionment of the chemical composition and importance of the polyacidic fraction. J. Geophys. Res. 107: D208091. doi: 10.1029/2001JD000522.

Pöschl, U., Martin, S.T., Sinha, B., Chen, Q., Gunthe, S.S., Huffman, J.A., Borrmann, S., Farmer, D.K., Garland, R.M., Helas, G., Jimenez, J.L., King, S.M., Manzi, A., Mikhailov, E., Pauliquevis, T., Petters, M.D., Prenni, A.J., Roldin, P., Rose, D., Schneider, J., Su, H., Zorn, S. R., Artaxo, P. and Andreae, M.O. (2010). Rainforest aerosols as biogenic nuclei of clouds and precipitation in the Amazon. Science 329: 1513-1515. doi: 10.1126/scien ce. 1191056 .

Procopio, A.S., Remer, L.A., Artaxo, P., Kaufman, Y.J. and Holben, B.N. (2003). Modeled spectral optical properties for smoke aerosols in Amazonia. Geophys. Res. Lett. 30: 2265. doi: 10.1029/2003GL018063.

Procopio, A.S., Artaxo, P., Kaufman, Y.J., Remer, L.A., Schafer, J.S. and Holben, B.N. (2004). Multiyear analysis of amazonian biomass burning smoke radiative forcing of climate. Geophys. Res. Lett. 31: L03108. doi: 10.1029/20 03GL018646.

Rap, A., Scott, C.E., Spracklen, D.V., Bellouin, N., Forster, P.M., Carslaw, K.S., Schmidt, A. and Mann, G. (2013). Natural aerosol direct and indirect radiative effects. Geophys. Res. Lett. 40: 3297-3301. doi: 10.1002/grl.50441.

Rizzo, L.V., Correia, A.L., Artaxo, P., Procppio, A.S. and Andreae, M.O. (2011). Spectral dependence of aerosol light absorption over newline the Amazon Basin. Atmos. Chem. Phys. 11: 8899-8912. doi: 10.5194/acp-11-88992011.

Russell, P.B., Bergstrom, R.W., Shinozuka, Y., Clarke, A.D., De-Carlo, P.F., Jimenez, J.L., Livingston, J.M., Redemann, J., Dubovik, O. and Strawa, A. (2010). Absorption Angstrom Exponent in AERONET and related data as an indicator of aerosol composition. Atmos. Chem. Phys. 10: 1155-1169. doi: 10.5194/acp-10-1155-2010.
Schafer, J.S., Eck, T.F., Holben, B.N., Artaxo, P. and Duarte, A.F. (2008). Characterization of the optical properties of atmospheric aerosols in Amazônia from long-term AERONET monitoring (1993-1995 and 19992006). J. Geophys. Res. 113: D04204. doi: 10.1029/2007 JD009319.

Schuster, G.L., Dubovick, O. and Holben, B.N. (2006). Angstrom exponent and bimodal aerosol size distributions. J. Geophys. Res. 111: D07207. doi: 10.1029/2005/JD006 328.

Scott, C.E., Rap, A., Spracklen, D.V., Forster, P.M., Carslaw, K.S., Mann, G.W., Pringle, K.J., Kivekäs, N., Kulmala, M., Lihavainen, H. and Tunved, P. (2014). The direct and indirect radiative effects of biogenic secondary organic aerosol. Atmos. Chem. Phys. 14: 447-470. doi: 10.5194/acp-14-447-2014.

Scott, C.E., Arnold, S.R., Monks, S.A., Asmi, A., Paasonen, P. and Spracklen, D.V. (2018a). Substantial large-scale feedbacks between natural aerosols and climate. Nat. Geosci. 11: 44-48. doi: 10.1038/s41561-017-0020-5.

Scott, C.E., Monks, S.A., Spracklen, D.V., Arnold, S.R., Forster, P.M., Rap, A., Äijälä, M., Artaxo, P., Carslaw, K.S., Chipperfield, M.P., Ehn, M., Gilardoni, S., Heikkinen, L., Kulmala, M., Petäjä, T., Reddington, C.L.S., Rizzo, L.V., Swietlicki, E., Vignati, E. and Wilson, C. (2018b). Impact on short-lived climate forcers increases projected warming due to deforestation. Nat. Commun. 9: 157. doi: 10.1038/s41467-017-02412-4.

Sena, E.T., Artaxo, P. and Correia, A.L. (2013). Spatial variability of the direct radiative forcing of biomass burning aerosols and the effects of land use change in Amazonia. Atmos. Chem. Phys. 13: 1261-1275. doi: 10.5194/acp-13-1261-2013.

Sena, E.T. and Artaxo, P. (2015). A novel methodology for large-scale daily assessment of the direct radiative forcing of smoke aerosols. Atmos. Chem. Phys. 15: 5471-5483. doi: 10.5194/acp-15-5471-2015.

Spracklen, D.V., Mickley, L.J., Logan, J.A., Hudman, R.C., Yevich, R., Flannigan, M.D. and Westerling, A.L. (2009). Impacts of climate change from 2000 to 2050 on wildfire activity and carbonaceous aerosol concentrations in the western United States. J. Geophys. Res. 114: D20301. doi: 10.1029/2008JD010966.

Ten Hoeve, J.E., Remer, L.A., Correia, A.L. and Jacobson, M.Z. (2012). Recent shift from forest to savanna burning in the Amazon Basin observed by satellite. Environ. Res. Lett. 7: 024020. doi: 10.1088/1748-9326/7/2/024020.

Ward, D.S., Kloster, S., Mahowald, N.M., Rogers, B.M., Randerson, J.T. and P.G. Hess, P.G. (2012). The changing radiative forcing of fires: Global model estimates for past, present and future. Atmos. Chem. Phys. 12: 10857-10886. doi: 10.5194/acp-12-10857-2012.

Received for review, May 12, 2019 Revised, December 13, 2019 Accepted, December 19, 2019 